NATALIA K. GORGOL*

\section{Analiza wraz z oceną relacji pomiędzy ideą Smart City a budową formy urbanistycznej na przykładzie Oslo i Wiednia}

\author{
The analysis of the relationship between \\ the idea of Smart City and the urban form \\ on the example of Oslo and Vienna
}

\begin{abstract}
Autorka przyjmuje tezę, że forma urbanistyczna stanowi kluczowy element w adaptacji istniejących miast w kierunku Smart City, jak iw tworzeniu nowych zespolow urbanistycznych. Artykut ma na celu zaprezentowanie relacji pomiędzy formą urbanistyczna a idea Smart City na przyktadzie dwoch miast Europejskich z roznyych regionow: miasta Europy Połnocnej - Oslo i Srodkowej - Wiednia. Celem pracy jest wy poza ramy charakterystycznego dla Eurno podejścia do miast $S$ mart City, osadzajacego sie na propagowaniu proekologiczcho podejśsia do architektury i urbanistyki, głównie dotyczacego zrównoważonego transportu i inwestycji w efektywność energetyczna. Elei planistów. Artykuł stanowi podsumowanie programu badawczego pt. Analiza wraz z oceną relacii pomiędzy ideą Smart City a budowa formy urbanistycznej miasta na przykładzie Oslo i Wiednia.

Abstract

The author believes that the urban form plays a key role in the adaptation of existing cities towards Smart City, as well as in the crealion of new smart urban tissue. The aricle aims to present he relationship between che urban form and the idea of Smart City on the to prove that the Smart City concept should be treated holistically in both urban and architectural contexts and go beyond typically European approach towards Smart City which is based on promoting an environment-friendly sollutions for architecture and urba while transforming a city into the Smart City is the crucial role of urban planning, planning methods and master planners. This paper is the final report of the research program 'The analysis of the relationship between the idea of Smart City and the urban form on the xample of Oslo and Vienn
\end{abstract}

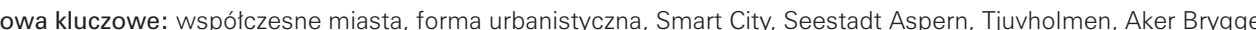

Keywords: contemporary cities, urban form, Smart City, Seestadt Aspern, Tjuvholmen, Aker Brygge

\section{Wprowadzenie}

W czasach nowej fali urbanizacji miasta szukają „pomysłu na siebie", idealnego modelu rozwoju, by sprostać wymaganiom, które przyniesie przyszłosć'. Truizmem jest stwierdzenie ze jedna wasciwa metoda rozwoju miasta nie istnieje, jedCik mino to coraz większą popularnośc zyskuje idea Smart City, jako uniwersalne remedium na problemy i wyzwania stawiane przed wspóiczesnymi miastami. Prawie każde miasto chce byc „smart - dokładnie takie jak to krotkie i wydajne stowo. Pięc liter zawierających w sobie mądrosc, spryt, czystość, inteligencję, szybkość, elegancje oraz bycie mod-

\section{Introduction}

the era of new wave of urbanisation cities are tearching for a method, an ideal development mod the meet the requirements that the future brings. city to a ruism to say that one proper method for popular as a universal remedy for the problems and city desires to be 'smart-exactly like this short and efficient word. Five letters that contain wisdom cleverness, purity, intelligence, speed, elegance
and being fashionable." Smart City has become the idea of Smart City is becoming more and more nym. "2 Smart City stało się świetnie sprzedającym się markejednak co oznacza właściwie termin Smart City w kontekście tworzenia miasta od podstaw lub jego adaptacji w kierunku idei Smart City?

Od wieków miasta były budowane według jasno określonych zasad urbanistycznych. Jako przykład przytoczyć można zarowno starożytne miasta greckie, czy rzymskie, budowane według sztywnych" regut, czy średniowieczne ośrodki, wznoszone przy ciekach wodnych i na wzgórzach, a takż - siowe układy barokowe. Przykłady historyczne można by mnożyć w nieskończoność. Wspótcześnie cięzko wskaźć jedn model, według którego rozbudowywane sa miasta, jednak można wyznaczyć wiodace trendy rozwoju miast, jak na pizykad Smart City. Jé li zatem spoirzymy na ides Smat Ciy jako na nowy spośb budowaia, czy adaptowania ws olczestych mias zagadiene formy urbadaptonej staje się istotnym, choć dotychczas marginalizowanym elementem wartości typu smart.

Rola formy urbanistycznej w budowie miasta Smart City (nazzie zahasto jest złożonym organizmem, dlatego rozwiązanie zawoczesnych technolojii wydaje sie niewystarczające, jak

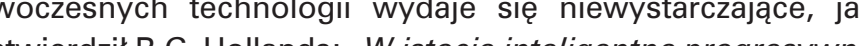
stien miasto (...) nie moze byc po prostu oznaczone jako inteligenthe, wdrazając zaawansowaną infrastrukture informatyczna lub tworzac autopromocyjne hasta." "Implementacja nowoczesnej infrastruktury komunikacyjnej (ICT), inwestycje w kapitał ludzki, czy dążenie do zrównoważonego rozwoju podkreslane w większości funkcjonujących definicji Smart City nie są wystarczające do przebudowy czy budowy dobrze funkSmart City konieczna jest analiza jak funkcjonuje miasto i ja kie są kluczowe elementy tworzące jego obraz.

Miasto powinno być postrzegane jako symbioza dwóch sykemów- struktury fizycznej (systemu miejkiego) dwoz sys symu spo-cznego (mieszkańcy miasta), które sa ze saz systepowiazane i oddziatuja na siebie nawzajem. ${ }^{5}$ Zatem n scisle pow ir podmiou (calośi). a nastepnie przejść do analizy poszcze-

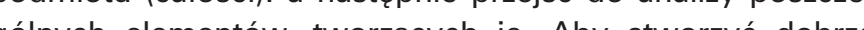

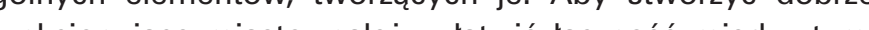
fukcon ja elementami. Lącznoś ta objawia się coraz częściej w próbach wy worzenia urbanistyki inluzywnej. Podejscie do miasta od ogolu do szczegolu zostalo unypuklone w wystawie The Crystal w Londynie, 7 poświęconej rozwiązaniom typu Smart City i zrównoważonemu rozwojowi miast.

które składają się na wizerunek miasta: ścieżki, krawędzie, rejony, węzły oraz punkty orientacyjne są kluczową cechą dobrze funkcjonującej przestrzeni miejskiej. . Elementy te związane są z fizyczną strukturą miasta, co potwierdza, ze zagadnienia związane z formą urbanistyczną nie mogą być marginalizowane w przeobrazaniu miast w kierunku Smart City. w związku z tym istnieje znaczna luka w definicji Smart City - zagadnienia formy urbanistycznej jako elementu fizycznego budującego miasto. a successful marketing slogan that sounds modern and attractive, but what does acctually the term 'Scratch For centuries, cities were ly defined urban principles. For instance, ancient Greek or Roman cities, built according to "rigid" rules; medieval cities, erected on hills, close to watercourses, and as concentric-axial Baroque urban forms. There are numerous historical examples. Nowadays, however, it is difficult to pinpoint on oped. Yet it is possible to identify the leading deverin the cities' development such as Smart City . If we perceive the idea of Smart City as a novelle way of building or adapting contemporary cities, the issue of urban form becomes an element of smart value, which has previously been marginalized.

The role of the urban th technological innovation seem to be insufficient As R.G. Hollands stated: 'In essence the smart progressive city (...) cannot simply formation technology infrastructure or through creimplementainvestments in human capital or promotion of sustainable growth emphasized in most of the existing Smart City' definitions are not sufficient to transform or erect a well-functioning city. In a pursuit of city functions and what are the cruciat adding up to the general image of the city.

A city should be perceived as a symbiosis of two systems - its physical structure (urban system/ and its social system (city's inhabitants), which are closely related and interact with each other. ${ }^{5}$ Therefore, a cily should be firstly looked at as the subject dividual eme Only afterwards the analysis of the into create a well-functioning city, it is necessary to facilitate communication between these elements. This communication is increasingly manifested in atempts to create inclusive urbanism. The topCrystap exoach towards a city is emphasized in The Thable urban development.

The basic elements defined by KLynch, which make up the image of the city: paths, edges, disricts, nodes and landmarks are a key feature of a well-functioning urban space. ${ }^{8}$ These elements are related to the physical structure of the city, which

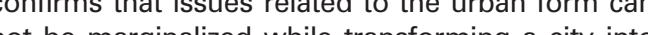
Smart City. Therefore, there is a significant city in the 'Smart City' definitions - the issue of the urban form as a physical element building a city.

S.Gzell stressed that the development of the city must only proceed with effective land-use planning and proper planning instruments applied at all levels. Therefore, the implementation of wide rang achieving a Smart City.

The literature review has show there are few studes oscillating around the relationship between 
S. Gzell podkreśla, że rozwój miasta musi postępować tylko w oparciu O skuteczne planowanie przestrzenne i wlasciwe narzędzia planistyczne stosowane na wszystkich poziomach. Zatem podstawowym elementem $w$ tworzeniu miasta typu smart jest także wdrożenie szeroko zakrojonych metod planowania urbanistycznego

Analizując literaturę natrafić można na badania oscylujące wokót relacji pomiędzy Smart City a planowaniem urbanistycznym. Przytoczyć warto wynki badań LG. Anthopoulos i A Vakali Naukowcy skupili sie na wspótistnieniu mistos Smart City i formy urbanistycznej oraz na wzajemnch rasta ciach miedzy nimi w kontekscie wzajemnego wspacia i ko-

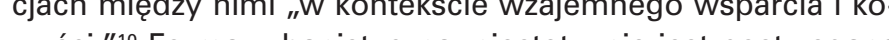
jako sktadowa Smart City, al jako niezalezny elestzegana

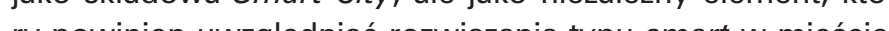
ry powiniena smart ciny, a de ako nezalezy ele Autorka stawia tezé, ze forma urbanistyczna i planowanie urbanisycze, kore, iewątpliwe whlywaja na funkjonowanie miast, powinny być traktowane jako składnik Smart City, a nie jako niezaleznny eleme

Inną istotną cechą definicji Smart City jest brak uwzględnienia kontekstu miasta. Idea Smart City pojawia się głównie w istniejących miastach, Smart City typu greenfield"11, takie jak Masdar, Songdo, Living PlanIT stanowią wyjątek. Dlatego w rzeczywistości idea Smart City powinna być traktowana jako wdrażanie rozwiązań typu smart $w$ istniejącą strukturę miasta, a nie tworzenie miasta od podstaw.12 Dlatego też kontekst konkretnego miasta jest jednym z kluczowych elementów. ${ }^{13}$

Kolejnym istotnym, mniej akcentowanym aspektem Smart City jest zagadnienie poszanowania tożsamości miasta. Według S.Vattano wiedeńska systematyka definiująca Smart City jako synergię sześciu elementów powinna być uzupełniona O siódmą pozycję: inteligentne dziedzictwo (smart heritage). ${ }^{14}$ Dodatkowy czynnik powinien odnosić się do sposobów zachowania historycznej tkanki miejskiej i poszanowania tożsamości miasta. Istnieje kilka miast, w których programy typu Smart City uwzgledniaj te dod wowa cecher Smarn Ci tenua we Włoszech oraz projekt Smart Retro wak $\mathrm{np}$. poszanowanie kontekstu jest istotne dla istniejących miast, w szczególności na miast Europejskich? Miasta Europejskie różnią się od siebie rożnym kontekstem geograficznym lub historycznym, mimo to wszystkie maja cechy wspolne: genius loci, ktory odzwierciedla ich historyczne i kulturowe dziedzictwo. Miasta te cechują się poszanowaniem ludzkiej skali i oferują wysokiej jakości srodowisko miejskie (przestrenie publiczne, zielen) przy zachowaniu odpowiedniej gęstości zabudowy. ${ }^{15}$ Ich wyróżniającą cechą jest dobrze zachowana tożsamosc i dzledzictwo historyczne. Dlatego też termin "Miasto Europejskie" może być postrzegany jako znak identyfikacyjny. ${ }^{16}$ G.Suttles opisat tę cechę jako "teksturę miasta", która składa się z: kontekstu, historii, architektury i mieszkańców danego miasta. ${ }^{17}$ Tekstura miasta może być porównana do tożsamości miasta.

Analiza istniejącego stanu wiedzy $w$ zakresie relacji formy urbanistycznej i idei Smart City wykazała trzy istotne luki w definicjach Smart City: zagadnienia formy urbanistycznej, kontekstu miasta i potrzeby zachowania tożsamości.
Smart City and urban planning. It is worth to highlight the results of research of L.G. Anthopoulo and A.Vakall. Researchers focused on the co-exisinterrelations between them 'in terms and on the support and benefit.'10 The urban form, unforttnately, is not perceived as an element of a Smart City, but as an independent element which should take smart solutions in a city into account. The author believes that the urban form and urban planning which undoubtedly affect cities' functioning should be treated as a component

Another significant gap in the 'Smart City' defini-
tions is the lack of the context of a city. As the idea of Smart City appears mostly in existing cities greenfield Smart Cities" newly-created smart cities such as Masdar, Songdo, Living PlanlT are rather an exception. Therefore, in reality the concep into the existing city structure rather than creating a city from scratch..$^{12}$ In such a perspective contex of a particular city is one of key features. ${ }^{13}$

Another crucial less-adressed aspect of Smart City is respecting the city's identity. According to S.Vattano the Vienna's systematic defining a well performing Smart City as a synergy of six smart
components should be broaden by the 7th one: smart heritage ${ }^{14}$ The additional factor should re fer to means to preserve historical urban tissue and the identity of the city. There are several smart programmes respecting the additional feature, such as e.g. Turin, Genoa in Italy and Smart Retro Project in Scandinavia. Why is the heritage of the city, especially in Europe, at utmost importance?
Although European cities differ from eachother of the geographical context or historical circumstances, they have one feature in common- their genius loci which reflects in their historical and cultura heritage. The cities respect human scale and offer high quality urban environment (public domains greenery) with the optimal density of the developbe perceived as an identification mark. 16 G. Suttles described this characteristic as the 'Texture of the city.' ${ }^{17}$ which consists of the city's: location, history architecture and inhabitants. The Texture of the city may be compared to the identity of a city.

The Analysis of the existing knowledge in terms of of Smart City revealed three significant gaps in the 'Smart City' definitions: the role of the urban form, the context of a city and the need of preserving the dentity of a city.

The definition of assumptions and selection of the analysis method

the systematics prenna and Oslo were based on which set out three elements necessary to create Smart City: vision (the direction of city's development), people (whom the city serves) and the process (the way of the city's transformation)..$^{18}$ The article focuses mainly on the vision, the process stage, providing a critical view of the outcames ot
the programms. same scheme, with particular emphasis on: the

ELEMENTY SKŁADOWEMART CITY NA BAZIE ZALOŻEN R.GIFFINGERA ISTOTNE W KONTEŚCIE RELACI POMIĘDZY SMART CITY A FORMA URBANISTYCZNA

\begin{tabular}{|c|c|c|c|c|c|}
\hline $\begin{array}{l}\text { INTELIGENTNA } \\
\text { MOBLNOSÉ- - smart } \\
\text { mobility } \\
\text { (transportilic) } \\
\end{array}$ & \begin{tabular}{|c|} 
INTELIGENTNE \\
SRODOWISKO - smart \\
environment \\
(zasoby naturalne) \\
\end{tabular} & 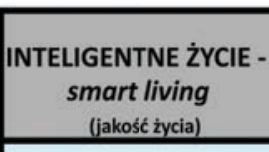 & $\begin{array}{c}\text { INTELIGENTNE } \\
\begin{array}{c}\text { ZARZADZANIE - smart } \\
\text { governance } \\
\text { (partycypacia) }\end{array} \\
\end{array}$ & $\begin{array}{c}\text { INTELIGENTNA } \\
\text { EKONOMIA - smart } \\
\text { economy } \\
\text { (konkurencyinoses) } \\
\end{array}$ & $\begin{array}{c}\text { INTELLIGENTNI } \\
\text { LUDZIE- smart } \\
\text { people } \\
\text { (spotecany iludarki kapitas }\end{array}$ \\
\hline $\begin{array}{l}\text { dostepnność w skali } \\
\text { lokalnej, lokalny system } \\
\text { transportu }\end{array}$ & $\begin{array}{l}\text { atrakcyjność warunków } \\
\text { naturalnych }\end{array}$ & $\begin{array}{l}\text { obiekty kulturalne } i \\
\text { wypoczynkowe }\end{array}$ & $\begin{array}{c}\text { świadomość } \\
\text { polityczna, } \\
\text { uczestnictwo w } \\
\text { podejmowaniu decyzji }\end{array}$ & innowacyjność & $\begin{array}{c}\text { poziom } \\
\text { wykwalifikowania/ } \\
\text { edukacji }\end{array}$ \\
\hline $\begin{array}{l}\text { dostępność w skali } \\
\text { międzynarodowej }\end{array}$ & $\begin{array}{c}\text { jakość powietrza (brak } \\
\text { zanieczyszzzeń) }\end{array}$ & warunki zdrowotne & $\begin{array}{l}\text { ustugi publiczne } \mathrm{i} \\
\text { spoteczne }\end{array}$ & przedsiębiorczość & $\begin{array}{c}\text { chę́ do podnoszenia } \\
\text { kwalifikacij przez } \\
\text { cale życie }\end{array}$ \\
\hline $\begin{array}{r}\text { dostepposiś do } \\
\text { nowoczesnych } \\
\text { technologii (ICT) } \\
\end{array}$ & $\begin{array}{c}\text { Śswidomość } \\
\text { ekologicna, ochrona } \\
\text { srodowiska }\end{array}$ & $\begin{array}{l}\text { indywidualne poczucie } \\
\text { bezpieczrnstwa }\end{array}$ & $\begin{array}{c}\text { sprawanai irrejirzysta } \\
\text { admininstracja, } \\
\text { zarzadzanie, }\end{array}$ & $\begin{array}{l}\text { wizerunek gospodarczy } \\
\text { i znaki towarowe }\end{array}$ & $\begin{array}{l}\text { socjalna i etniczna } \\
\text { różnorodność }\end{array}$ \\
\hline \multirow[t]{4}{*}{$\begin{array}{c}\text { zrównowazione, } \\
\text { innowacyjne i } \\
\text { bezpieczne systemy } \\
\text { transportu }\end{array}$} & $\begin{array}{c}\text { zarzadzenie } \\
\text { odnawialnymi } \\
\text { zasobami }\end{array}$ & jakośćc zabudowy & $\begin{array}{l}\text { strategie polityczne i } \\
\text { perspektywy }\end{array}$ & produktywność & elastyczność \\
\hline & & ośrodki edukacyine & & $\begin{array}{l}\text { elastyczność rynku } \\
\text { pracy }\end{array}$ & kreatywność \\
\hline & & atrakcyjność turystyczna & & $\begin{array}{c}\text { międzynarodowa } \\
\text { integracja }\end{array}$ & $\begin{array}{c}\text { kosmopolityzm/ } \\
\text { otwarność }\end{array}$ \\
\hline & & spójność społeczna & & $\begin{array}{l}\text { zdolność do } \\
\text { transformacii }\end{array}$ & $\begin{array}{l}\text { uczestnictwo wìyciu } \\
\text { publicznym }\end{array}$ \\
\hline
\end{tabular}

Tab 1. Opracowanie własne autora na podstawie pracy badawczej R. Giffingera

Definicja założeń i wybór metody analiz

Analizy Wiednia i Slo prowadzone byly w oparciu O systematykę zaproponowaną przez $\mathrm{H}$. Van Beurden, ktora wyznaczyła trzy elementy konieczne do stworzenia Smart City: wizje (kierunek rozwoju miasta), ludzi (którym miasto służy) oraz proces (sposób przemiany miasta). ${ }^{18}$ Artykuł skupia się głównie na wizji i procesie oraz krytycznym spojzzeniu na uzyskany efekt. Studium poszczególnych przypadków przeprowadzon zostało według tego samego schematu. Ze szczególnym zostało wedug tego samego schematu. Ze szczegolnym uwzględint

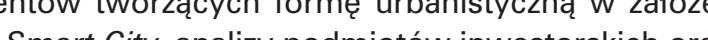
zastosowanych środków planistycznych.

Giffinger definiuje Smart City jako synergie sześciu elementów składowych: smart economy, smart mobility, smart environment, smart people, smart living, smart governane. 19 Poniżej przedstawiona została analiza systematyki wiedeńskiej w kontekście relacji pomiędzy formą urbanistyczną a ideą Smart City. Obszar badań zawężony został do czterech składowych: smart mobility, smart environment, smart living oraz smart governance. Szczegółowe aspekty składowych istotne ze względu na prowadzone badania oznaczone zostaty w kolorze błękitnym

Po zdefiniowaniu podzbioru wartości typu smart, istotnych z perspektywy urbanistyczno-architektonicznej przeprowadzona została analiza korelacji składowych Smart City z elementami tworzacymi formę urbanistyczną. Celem było wykazanie zagadnien istotnych $w$ dyspucie $O$ roli formy urbanistyczne w tworzeniu Smart City oraz oczekiwanych rezultatów przy zastosowaniu danego elementu składowego formy urbanistycznej. Ponizej zamieszczone zostały rezultaty analizy: correlation of Smart City components and urban form elements forming in the chosen Smart City examples. The analysis of investor entiy and ap pled planning masures has been provid and compents: smart economy, smart morgy of six environment, smart living, smart governance..$^{19}$ The article provides the analysis of the Vienna's systematics in the context of the relationship between the urban form and the Smart City idea. The research Tea has been narrowed down to four components: smart governance. The elements of the components relevant to the conducted research have been marked in blue. (Table Tab 1. Author's own elaboration based on R. Giffinger's research work.) Having defined a subset of smart values which are significant in terms of the urban and architectura perspective the analysis of the correlation of the was carried out. The aim was to demonstrate issues relevant to the dispute about the role of urba form in creation of a Smart City. The table presents expected results using a given component of the urban form in accordance to Smart City value. Table Tab 2 Author's own elaboration

\section{Vienna as Smart City - case study}

riteria of the research material Vienna, which is placed the highest positions in the ranking for the world's most liveable cities for implementation of Smart City values in Europe. The city is an unrivaled role model for other European Austria was chosen as the final research group due to the fact that smart programms are pursued not 
ANALIZA KORELACI SKLADOWYCH SMART CITYWG SYSTEMATYKI WIEDENSSKIEJ Z ELEMENTAMI TWORZACYMI FORMĘ URBANISTYCZNA

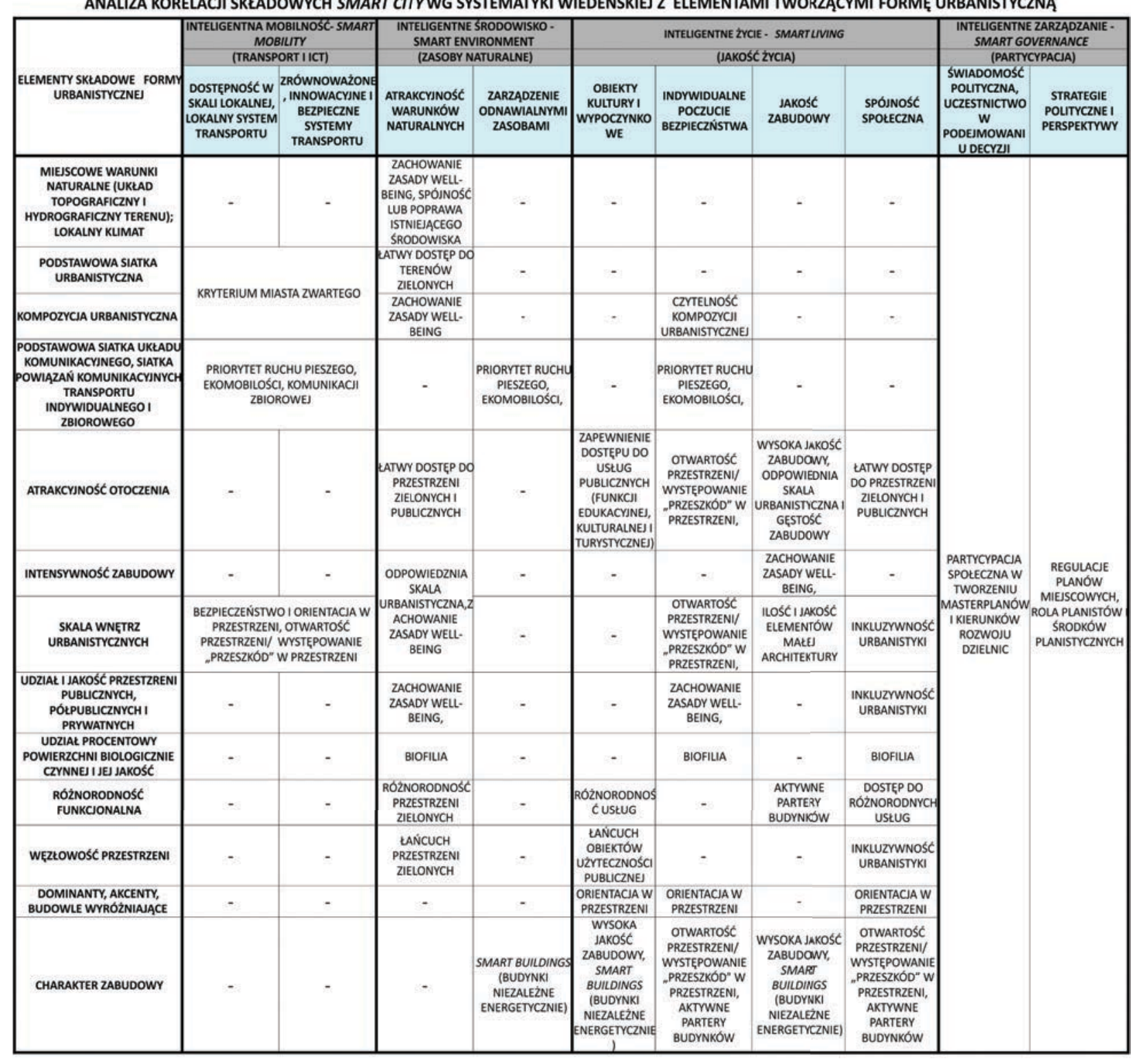

Tab 2. Opracowanie własne autora

Wiedeń jako Smart City - studium przypadku

Kryteria doboru materiału badawczego

Wiedeń, zajmujący od lat najwyższe lokaty w rankingach najlepszych miast do życia, ${ }^{20}$ jest najbardziej znamienitym przykładem skutecznego wdrażania idei Smart City w Europie oraz niedoścignionym wzorem dla pozostałych miast europejskich "podróżujacych" w kierunku Smart City. Stolica Austrii została wybrana do ostatecznej próby badawczej taki̇e ze wzgledu na to, że działania typu smart prowadzone sạ nie tylko w wybranych dzielnicach, czego przykładem jest Seestadt Aspern, ale przede wszystkim w kontekście całego miasta.

Wizja Smart City realizowana przez miasto

Miasto wdraża postulaty idei Smart City w oparciu O systematykę opracowaną przez R.Giffingera, ze szczególnym naciskiem na inteligentną mobilność (smart mobility), inteligentne środowisko (smart environment) oraz inteligentne życie oraz środodzielnicy typu smart, dzięki następującym czynnikom ${ }^{24}$ :

Aspern, but also intricts, for instance in Seestadt Vienna as Smart City - the vision

The city implements the postulates of the Smart City idea based on the systematics developed by R.Giffinger, with particular emphasis on intelligen mobility, intelligent environment, intelligent living the the of smart mobility in the scale of the entire of ecomobility (bicycle transport, public transport pedestrian traffic and car sharing) and to reduce the individual car traffic to the level of about $15 \%$ by $2030 . .^{2}$ In terms of the smart environment agenda there is the requirement tokeep indicators of he biological area in the city at the level of at leas $50 \%$ of the city area).

the city are noted that projects implemented in cial participation and multi-sector cooperation (eg.

- Iokalizacji ogólnodostępnych zielonych terenów rekrea- wisko mieszkaniowe (smart living). Do najistotniejszych działan w obszazze smat mobility w skali calego miasta należą inwestycje we wzmocnienie roli ekomobilności (transportu rowerowego, komunikacji publicznej, ruchu pieszego oraz car sharing oraz redukcji indywidualnego ruchu kołowego do poziomu ok $15 \%$ do 2030 r. ${ }^{21}$ w zakresie zagadnień smart environment $n$ uwage zasługuja wymagane wskażniki powierzchni biologiczne $w$ mieście (min. $50 \%$ powierzchni całego miasta).

Podkreślić należy, że projekty realizowane w mieście cechuja się wysokim udziałem partycypaci społecznej i wspótpracy mię wzysektorowej, czego przy com jest dziel wspotpracy a Wiedeń pokryty jest $w$ całości miejscowymi planami zagospodarowania przestrzennego.

Analiza podmiotów inwestorskich wykazała, że głównym Analiza podniotow inestorskich wykazala, ż glownym Wieden. Okolo 60\% mieszkn Wieden. Okolo 60\% miesz. nansowan przez urza mianta całościowy lub częściowy.

\section{Aspern Seestadt - wizja}

Położenie jednego $z$ największych placów budowy Europy ${ }^{23}$ nie jest przypadkowe. Dzielnica Aspern Seestadt została zaplanowana na strategicznej osi rozwoju Wiedeń- Bratysława w regionie CENTROPE, który rozwijać się ma jako wiodący ośrodek badań naukowych. Założenie urbanistyczne powstaje w oparciu O masterplan oraz odpowiednik Polskiego miejscowego planu zagospodarowania przestrzennego, które zostały opracowane przy współudziale mieszkańców oraz współpracy międzysektorowej pomiędzy urzędem miasta, prywatnymi inwestorami oraz instytutami badawczymi, co w pisuje sie w nurt smart governance. Dzielnica jest projektem wspólnym miasta oraz inwestorów prywatnych.

Aspern zaliczyć można do projektów smart typu greenfield dlatego forma urbanistyczna stanowi ważny aspekt w kreowaniu dzielnicy. Masterplan dzielnicy zakłada wytworzenie

- położeniu na osi CENTROPE

- tatwemu dostepowi do transportu publicznego i centrum miasta (linia metra łączy peryferyjnie położoną dzielnicę z centrum miasta w czasie ok. 25 minut)

- wysokiemu udziałowi przestrzeni ogólnodostepnych (połowe powierzchni dzielnicy stanowić mają parki, place, ulice) z akcentem na zapewnienie różnorodności przestrzeni publicznych

Aspern district). Vienna is covered entirely by local spatial development plan

The analysis of investor units has shown that the of urban lands. About $60 \%$ of the inhabitants live in a building stock financed by the city hall ${ }^{22}$ The financing is of a total or partial nature.

Aspern Seestadt - vision

The location of one of the largest construction sites in Europe ${ }^{23}$ is not accidental. The Aspern Seestad Bratislava development in the CENTROPE region which is to develop as a leading research cente The urban structure is based on the masterpla and the equivalent of the Polish local spatial development plan. They were created with the inhabiants' participation and multi-sector cooperation beineen the city hall, private investors and research prend). The district is a joint venture of the city and private investors.

Aspern can be classified as a greenfield Smart City project. This is why the urban form plays an important role in the creation of district. According to he masterplan the area should be become smart - location on theowing factors's

- accessibility to public transport and the city center (the metro line connects the peripherally located district with the city center in about 25 minutes)

high share of public spaces (half of the area of the district is to consist of parks, squares, streets with the goal to provide the diversity of public
spaces
diversified functional structure of buildings (the

diversified functional structure of buildings (the of housing and the number of jobs provided by service, educational functions, etc.)

public recreational, green areas with a water reservoir in the heart of the urban plan

red and introducing the postulate of energy consumption at the level of 2000 Watt per capita; - enforcement of smart buildings

\section{- high urban and architectural standards}

Aspern - the analysis of strategies with evaluation f undertaken actions and their impact on the functioning of the city

The results of the analysis is presented in the tab Tab 3. jest osiągnięcie równowagi pomiędzy udziałem zabudo wy mieszkaniowej oraz ilością miejsc pracy zapewnionym przez funkcje usługowe, edukacyjne etc.) cyjnych ze zbiornikiem wodnym w sercu założenia urbanistycznego

- promowaniu inwestycji niezależnych energetycznie, redukujących zużycie zasobow naturalnych oraz wprowadzeniu postulatu zużycia energii na poziomie 2000 Watt w przeliczeniu na mieszkańca;

- promowaniu budynków typu smart building

- wysokim standardom urbanistyczno-architektonicznym
What seems possitive is that the urban structure spential development plan. As in dovalive shoud principles of inhabitants' participation in decisionmaking and multi-sectoral cooperation. However, the parameters included in the plan remain controversial, in particular: the size of green areas along pedestrian routes; the proportion of paved areas to the biologically active area within quarters in ground floor level of the building stock in relation to the size of existing buildings. is breated according tothe strictly defined loca and a local spatial development plan based on the 


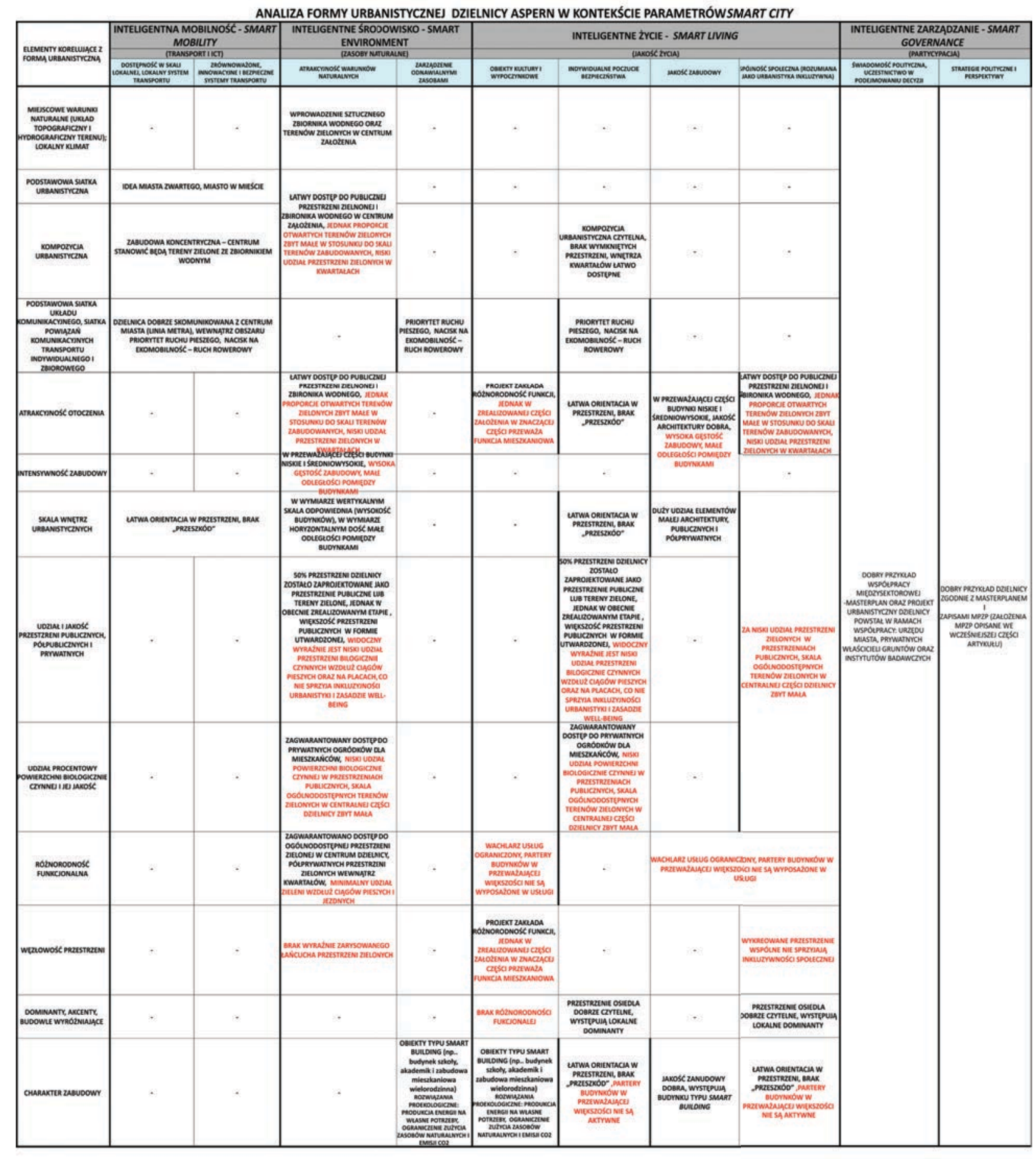

Tab 3. Opracowanie własne autora

Aspern - analiza przyjetych strategii wraz z ewaluacja podjetych działań i ich wpływu na funkcjonowanie miasta

Wyniki analiz prezentuje tabela zamieszczona powyżej.

Do pozytywnych cech dzielnicy zaliczyć można kreowanie struktury urbanistycznej w oparciu O ściśle określony miejscowy plan zagospodarowania przestrzennego. Innowacyjne jest także tworzenie masterplanu i miejscowego planu zagospodarowania przestrzennego $\mathrm{w}$ oparciu $\mathrm{O}$ zasady partycypacji społecznej i współpracy międzysektorowej. Dyskusyjne pozostają jednak parametry zawarte w planie, w szczegölności udział przestrzeni zielonych wzdłuz ciągów pieszych, proporcje terenów utwardzonych do powierzchni biologicznie czynnej w obrębie kwartałów w części ogólnodosteepnej oraz udzia aktywnych parterów w stosunku do istniejącej zabudowy.

Dzielnica Seestadt Aspern reklamuje się jako idealna przestrzeń do życia, forma miasta w mieście. Niestety, obecnie jakość przestrzeni miejskiej nie spełnia wszystkich postulatów, jakie twórcy dzielnicy wyznaczyli sobie. Być może wynika to

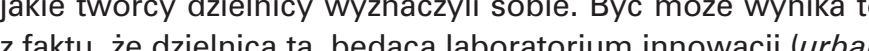
z faktu, ze dzielnica ta, będąca labo

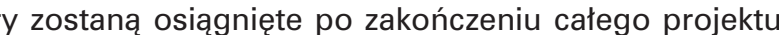
które planowane jest na ok. 2030 rok. ${ }^{26}$

\section{Oslo jako Smart City - studium przypadku}

\section{Kryteria doboru materiału badawczege}

Miasta skandynawskie w tym Oslo, charakteryzuja się dobrze rozwiniętą infrastrukturą oraz kompaktowym podejściem do planowania urbanistycznego i tworzenia struktury miejskiej. Dodatkowa istotną cechą jest poszanowanie ludzkiej skali w kontekście zabudowy. w zasadzie miasta te nie muszą „rozbudowywać sie" poza istniejace granice, aby dopasować sie do zwieksszajacej liczby mieszkańców. Adaptacja na potrzeby Smart City moǰliej liczby mieszkańców. Adaptacja na potrzeby Smow Cly mozliwa jest poprzez modernizacje istniejącej zabudowy, akupunkturalne uzupełnienie tkanki miejskiej, lub jak w przypadku Oslo ", Odzyskiwanie" terenów wzdłuz linii brzegowej. Stolica Norwegii została zakwalifikowana do ostatecznej próby badawCzmart City, zarówno tych w mniejszej skali, jaki i prób tworzeni obszarów miasta na podobnych zasadach jak w Aspern. ${ }^{27}$

\section{Wizja Smart City realizowana przez miasto}

Według przedstawicieli AHO (The Oslo School of Architecture and Design) Oslo „podróżuje” w kierunku Smart City za przykładem płynącym nie tylko z Wiednia, ale także Kopenha gi. Zainteresowane jest tworzeniem eksperymentalnych ulic, na wzór rozwiązan duńskich. Kolejnym istotnym postulatem w polityce przestrzennej Oslo jest sci miasta, tak aby szeroki wach

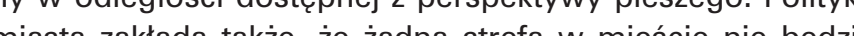
miejsca spotkań towarzyskich.

Na podstawie analizy istniejacego stanu wiedzy w zakresie projektów typu Smart City prowadzonych w mieście wynika ze równolegle prowadzone jest kilka projektów, skupiających się na różnych aspektach idei Smart City. Na uwagę zasługuja następujące inicjatywy: Smart Retro, Hovinbyen, Futurebuilt, Digital Urban Living, Oslo City Bike Project i Fjordbyen.

\section{Kvadraturen - wizja}

Opisane we wcześniejszej części artykułu skandynawskie podejscie do kompaktowej urbanistyki doskonale obrazuje inicjatywa Smart Retro podjęta w dzielnicy Kvadraturen w Oslo. Kvadraturen, dawne miasto króla Christiana IV, zlokalizowan jest w centralnej części Oslo. Posiada ona dobrze rozwinięta sieć powiązan komunikacyjnych i gessta, dobrze rozwinięta
Oslo as Smart City - the case study The selection criteria of the research material Scandinavian cities, including Oslo, have welldeveloped infrastructure and their characteristic planning and urban structures. Additionally, these cities respect human scale in terms of their development. In principle, these cities do not have to expand beyond the existing boundaries to adapt to the increasing number of inhabitants. The transformation into Smart City is possible stock, the modernization of existing building in the case of Oslo, regaining the areas along the shoreline. The capital of Norway was qualified for the final research group due to the diverse nature of the Smart City projects, both those on a smal(1) create areas similar Aspern. ${ }^{27}$

Oslo as Smart City - the vision

According to representatives of AHO (The Oslo School of Architecture and Design), Oslo 'is traveling towards Smart City following the example for lowing the Danish experimental streets, folpostulate in Osso's spatiale. Another importan the polycentricity of the city, so that a wide range ed within the walking distance. The city's goal is to provide every zone in the city with a square or a social gathering place within 200 meters.

ased on the analysis of the existing knowledge the scope of Smart City projects conducted carried out simultaneously. Most of therm focus on various aspects of the Smart City idea. It is worth to mention following initiatives: Smart Retro, Hovinbyen, Futurebuilt, Digital Urban Living, Oslo City Bike Project and Fjordbyen

Kvadraturen - the vision

The Scandinavian approach to compact urban planning is aptly illustrated by the Smart Retro initiative undertaken in the Kvadraturen district in Oslo. Kvadraturen, the former city of King Christian developed local transport system and dense, wella historical character and well-preserved identity with a high share of historical buildings in urban tissue. This should indicate that this place is teeming with life and prospering well. However, in Kvadraturen the degradation process is easly noticable. The degradation is related to: depopulation, lack of diversity of services (strictly office district) andshare of uninhabited development, high crime rates and a low sense of security. The unused potential of the district and the city's policy based on compact urbanization resulted in the Smart Retro initiative.

According to the Smart Retro Program, the Smart City implementation process requires the followting, urban tissue infill, startups and new public spaces for residents. ${ }^{28}$ The idea of retrofiiting is 
tkankę miejską. Ponadto, dzielnica posiada historyczny chaPowana tożsamość z wysokim udziałem budynków historycznych w tkance miejskiej. Cechy te powinny wskazywać na to, że miejsce to tẹtni życiem i dobrze prosperuje, jednak w Kvadraturen odnotować można widoczny proces degradacji zwiazzany z: wyludnieniem, brakiem różnorodności usług (dzielnica stricte biurowa) i aktywizaci społecznej, niszczejącă tkanką miejska, z dużym udziałem pustostanów, wysokimi wskaźnikami przestepczości oraz niskim poczuciem bezpieczeństwa. Niewykorzystany potenciat dzietpoczucien wezle nicy i poliyka miasta osadzajea sien nomi-

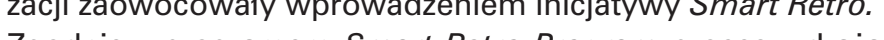
Zgodn z prort Ciy wymaga

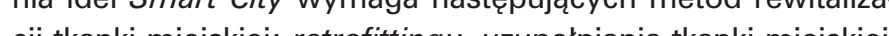
cji tkanki miejskiej: retofteingu, uzupeniania tkanki miejskiej, starupow oraz tworzenta przestzeni publicnych dla mieszkancow. Ide retrill istniejących obiektów do wspólczesnych potrzeb użytkowników i zastosowaniu rozwiazan O wysokiej jakości proekologicznej. Jest to element spójny z polityką Smart City władz miasta, opierająca się głównie na inwestycjach w budynki niezależne energetycznie. Uzupełnienie tkanki miejskiej według twórców programu powinno mieć charakter akupunkturalny i skutkować zwiększeniem liczby użytkowników i poziomu urbanizacji miasta. Ostatni czynnik wpisuje się w ogólną politykę miasta - dążeniu do utrzymania zwartego miasta. Startupy mają na celu zapewnienie inteligentnych usług (smart services) dla mieszkańców. Tworzenie przestrzeni publicznych ma wspierać rozwój inkluzi społecznej, a wytworzenie więzi pomiędzy mieszkańcami miasta powinno ożywić przestrzenie publiczne.

Dogęszczanie tkanki miejskiej w przypadku Kvadraturen następuje pod dwoma warunkami. Po pierwsze, dokonywana jest analiza istniejącej zabudowy i ocena możliwości jej adaptacji do wspótczesnych wymagań ekologicznych, technologicznych i technicznych. Budowa nowej zabudowy w dzielnicy Kvadraturen jest możliwa pod warunkiem, że dana nieruchomość nie jest zdatna do adaptaci. Adaptacja nazwana przez twóćń programu Smart Rerto - retrofiiting z zatoż pia jest wyrazom poszanu Smart Rerto - retrofiling z zloz pra jest wrazem

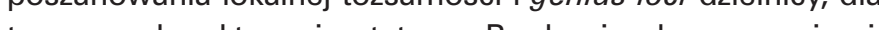
tego mazhár proyse może odbywać się

Przykład ten został przytoczony ze względu na założenia programu Smart Retro, istotne w dyspucie nad rolą formy urbanistycznej w tworzeniu wartości typu smart. Dzialania podjęte $w$ tej dzielnicy cechują się kompaktowym podejsciem do planowania urbanistycznego; poszanowaniem tożsamości i historycznego charakteru miasta i typowej formy urbanistycznej. Adaptacja i transformacja istniejącej tkanki miejskiej jes kluczowym elementem w dązeniu Oslo do zrównoważonego rozwoju. Przykład ten obrazuje, ze możliwe jest uzyskanie wartosci typu smart poprzez transformację istniejących, „starych" obiektów w obiekty dopasowane do współczesnych wymagan, zarowno w kontekscie funkcji i formy, jak i efektywności energetycznej, oraz proekologicznych rozwiązań w myś zasady, że "Stare pomysty mogą czasem korzystać z nowych budynków. Nowe pomysty muszą korzystać ze starych budyn- based on adapting existing facilities to contemporary users' needs and applying high-quality with with the Smart City policy of the city authorities, dent buildings. The infill of the urban tissue according to the program should be acupunctura and result in an increasing number of users and the urbanization level of the city. The last factor is part of the general policy of the city - goal to maintain a compact city. Startups are aimed providing smart services for residents. The cresion, and interactions between the inhabitants are to revive public spaces.

The infill of an urban tissue in the case of Kvadraturen may occur under two conditions. Firstly, the analysis of existing buildings and theassessmen of its adaptation possibilities to contemporary ecoare carried out. The erection of a new building in the district of Kvadraturen would be only possible if the property is not adaptable. The adaptation 'retrofititing' is an expression of respect for the local identity and the genius loci of the district. This why it is a priority. Secondly, densification can not take place neither at the ext

because of the agenda of Smart Retro project which is essential in the dispute over the role of the urban form in creating smart value. The measures undertaken in the district characterize as a compact urban planning; respecting the identity urban form. The adaptation and transform typic existing urban fabric is a key element in the OsIo's pursuit of sustainable growth. This example shows that it is possible to obtain smart values by transforming existing 'old' buildings into buildings meeting the requirements of present times,

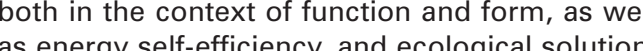
To conclude: 'Old ideas can sometimes use new buildings. New ideas must use old buildings."29 The thorough analysis of the district has shown, however, that the initiatives undertaken in the district are to a large extent the revitalization of tissue.

Fjordbyen: Tjuvholmen and Aker Brygge -

The Fjordbyen project (The Fiord City) plays a key role in the construction of Oslo's urban the project is based on the revitalization ization of the former harbour areas, and revitalquisition of new sites for development, through the shedding of a islands on which public facilities are located, including the National Opera. Along the shoreline, there are planned or errected buildings- residential and service one as well as public facilities, mainly museums (eg. New National Museum of Edvard Munch, New project is being implemented at the initiative of

the city of Oslo. The revitalized area stretches ków. "229 Szczegółowa analiza dzielnicy wykazała jednak, że podnoszą znamiona rewitalizacj przestrzeni, a nie tworzenia nowej tkanki miejskiej.

Fjordbyen : Tjuvholmen i Aker Brygge - wizja

Projekt Fjordbyen (The Fiord City) odgrywa kluczowa role w budowie formy urbanistycznej Oslo. Projekt ten opiera sie na rewitalizacij linii brzegowej miasta, zarówno poprzez rewitalizacie dawnych terenow potowych, jak i uzyskanu nowych terenów przznaczonych po zabudowe, poprez nadsypywanie pewnego rodzaju wysp, na których zlokal(uzyera zostały Nud publiczej, glownie muze (n. nowe Narodowe Muzeum Edva ga Muncha, Nowa Beblotek Narodowa, Nowe Muzeum Narodowe). Projekt ten realizowany jest $z$ inicjatywy władz miasta Oslo. Rewitalizacyjny teren rozciąga się od Bygdøy do Ormoy. Celem projeku bylo stworzenie ok. 9000 nowych budynkow mieszkalnych, przeznaczonych dla ok. 8.000 mieszkanców oraz ok. 42.000 miejsc pracy.

Analiza podmiotow kazała, że w Oslo przeważa udział własności prywatnej, a większość podmiotów inwestorskich stanowią prywatne firmy. ${ }^{30}$

Tab 4. Opracowanie wasne autora

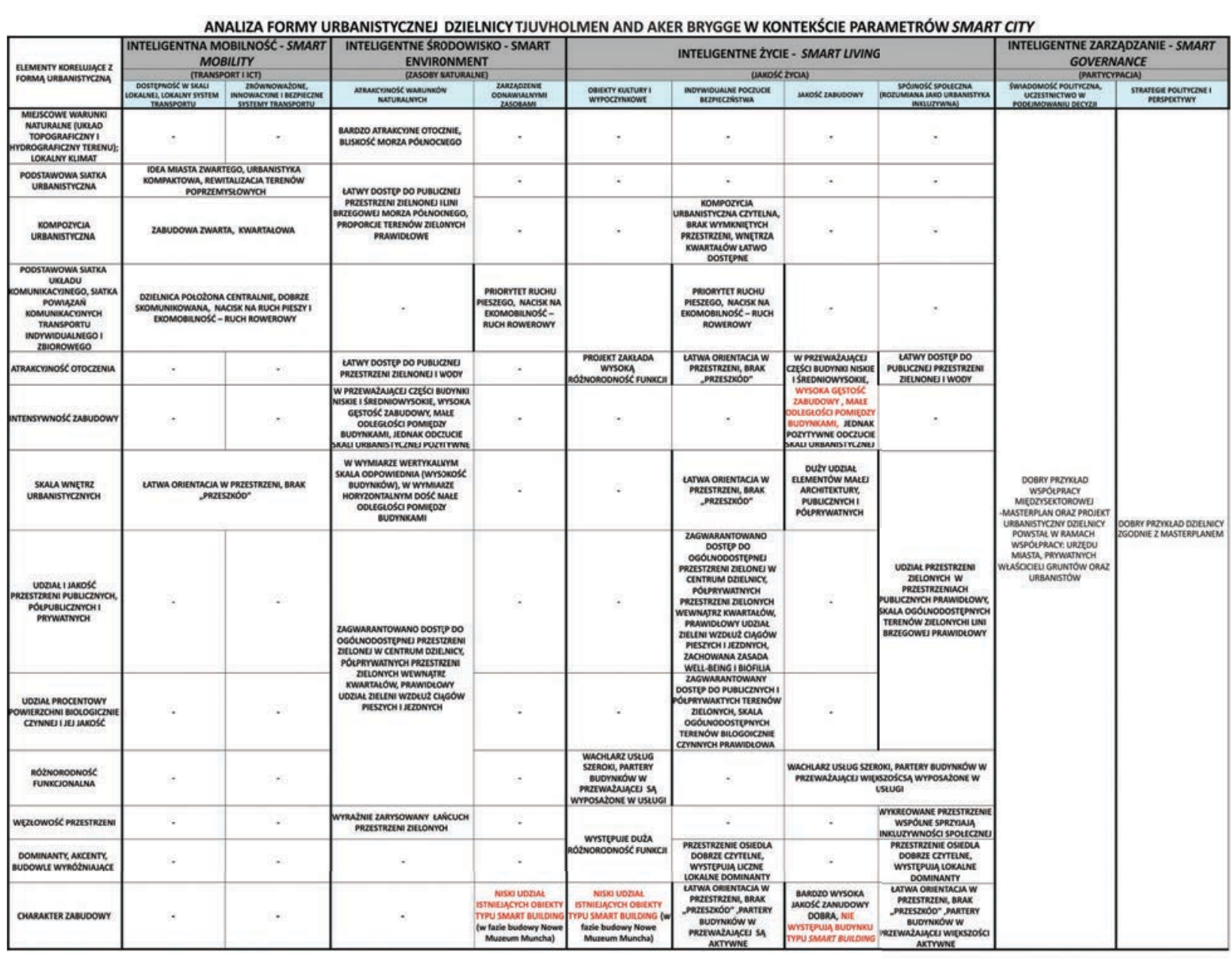

from Bygdøy to Ormoy. The aim of the project is designed for approx. prox. 42,000 employees.

structure has of the investors and the ownership are private companies..$^{30}$

Fjordbyen: Tjuvholmen and Aker Brygge -

the analysis of strategies with evaluation

ff undertaken actions and their impac

on the functioning of the city

The results of the analysis of the urban form of the own elaboration)

Despite the fact hat the district was not designed as a Smart City, there are many was nents typpica for this idea. The assesment of the quality of the urban space has shown that the created spaces contribute to inclusive urban planning. The principles of well-being and biophilia are successfully the hanks to the urban planning measures applied. The reason for this, high quality of public and semi-public spaces and numerous, well-thought through elements of street architecture, sculpures etc. ership prevails in Oslo, and most of the investors 


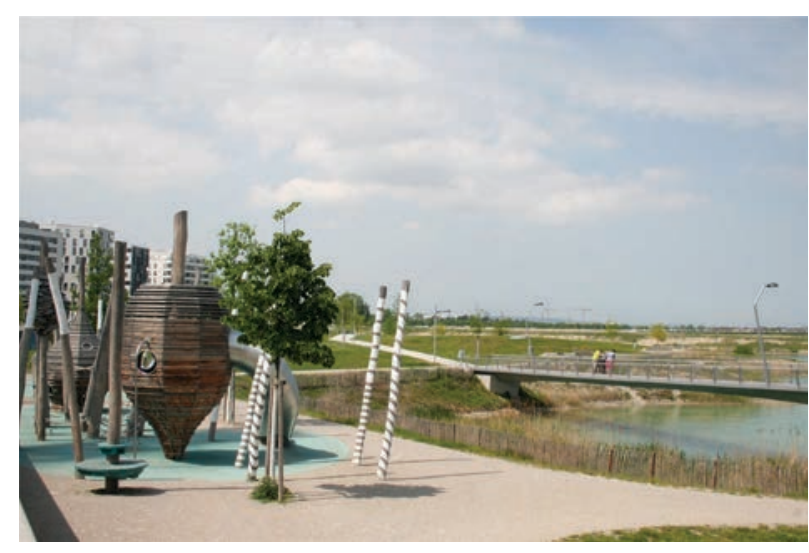

II. 1. Zdjęcie autora./ Own collaboration
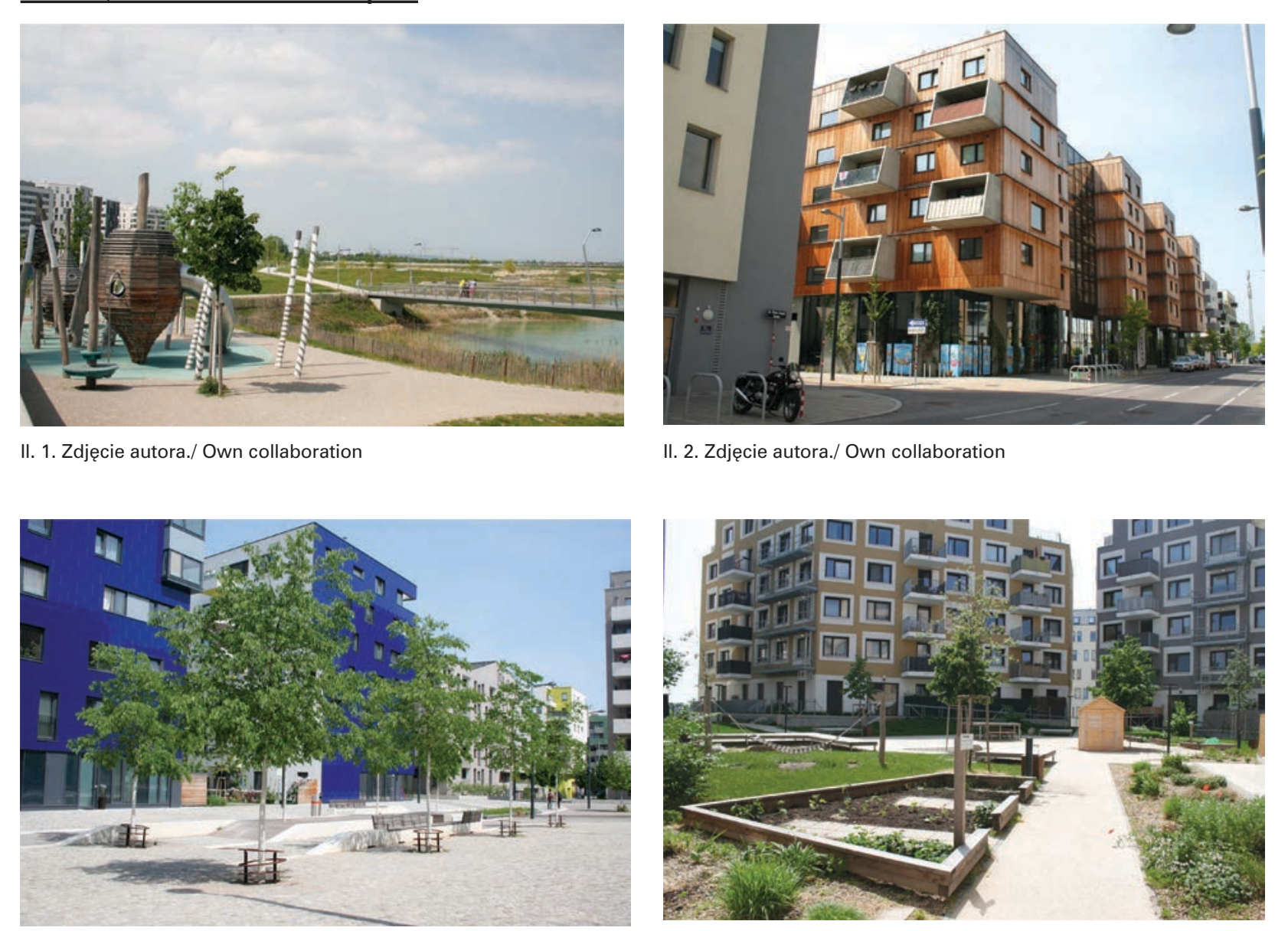

II. 3. Zdjęcie autora./ Own collaboration

Oslo - Tiuvholmen i Aker Brvgge

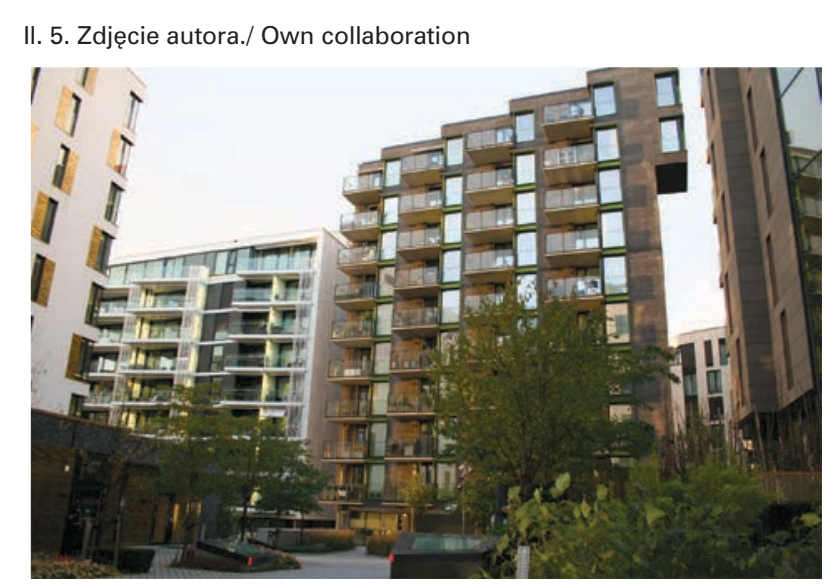

II. 6. Zdjęcie autora./ Own collaboration

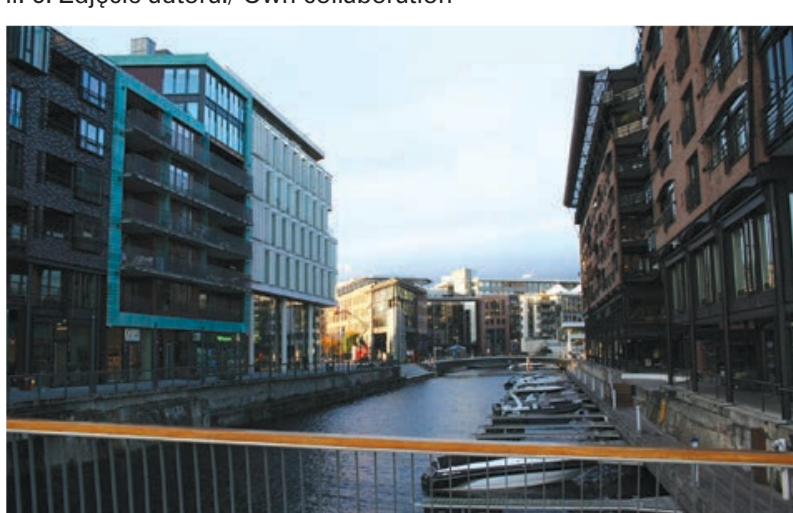

II. 2. Zdjęcie autora./ Own collaboration

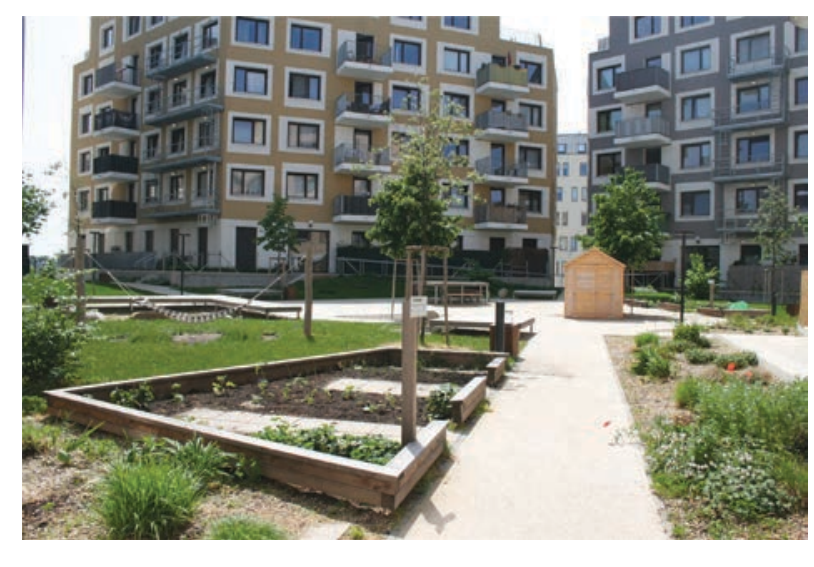

II. 4. Zdjęcie autora./ Own collaboration

II. 7. Zdjęcie autora./ Own collaboration

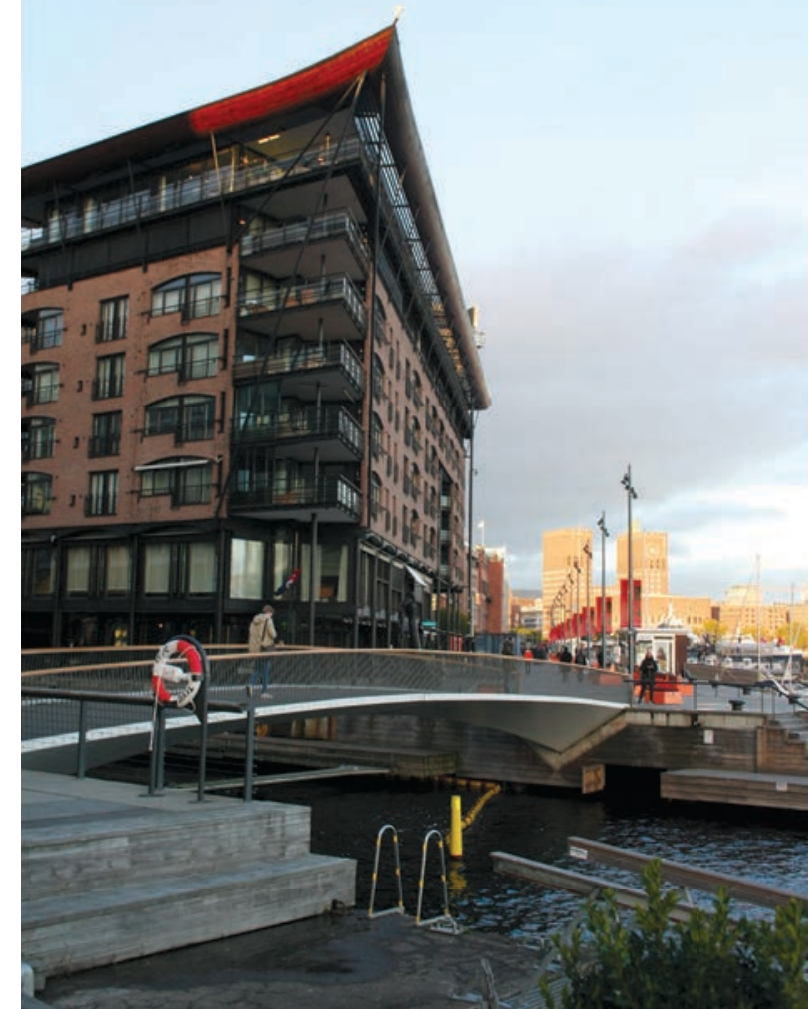

Fjordbyen : Tjuvholmen i Aker Brygge - analiza przyjetych strategii wraz $z$ ewaluacia podjetych dzialan i ich wplywu na funkcjonowanie miasta

Wyniki analizy form

Pomimo, że dzielnica nie powstawała $w$ zgodzie $z$ trendam Smart City odnotować można liczne elementy wspólne z ta ideą. Analiza jakościowa założenia urbanistycznego wykazała, że wykreowana przestrzeń sprzyja inkluzywnej urbanistyce, zasadom well-being i poczuciu biofilii. Zastosowane

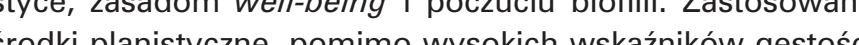
intensywności zabudowy pozwaja na pozytywny odbió przestzi. w duzej mierze zoz p jakośc wzestzeni publiczeych i pópu na wysoka dałosc O jakosc przestzen publicznych i pópubliczych oraz

The evaluation of innovation scale of selected reearch objects

The Viennese example is undoubtedly innovative of the project but also due to conducted research in the optimal settlements of the future. Due to the field of this research, the design approach from urban scale to architecture and the emphasis on the role planning measures and the process of urban planning seem to be the most vital aspects. The atshare of energy-independent buildings with a large be noted, though such goals are set commonly nowaday

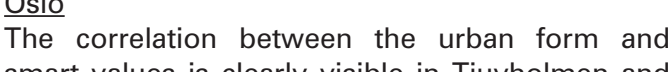
smart values is clearly visible in Tjuvholmen and of smart living, smart environment, smart gov ernance, smart mobility. These are all aspects of R.Giffinger's systematics, according to this article , which are considered significant in terms of the study of Smart City's urban form. The example of Tjuvholmen and Aker Brygge proves that smat value may be achieved without the extensive use shoud be considered innovative.

\section{Summary - the validation of the assumption}

criterion

The aim of the article was to prove there is the relationship between the urban form and the idea demonstrate that in order to obtain a smart value there are three factors necessary to be taken into account: context of a city, its identity and the emphasis on the role and quality of an urban form. The article pointed out the correlation of elemen of the urban form and the idea of Smart City.

(Aker Brygge silnie wyczuwa formy urbanistycznej i wartosci typu smart. Dzjeln nia postulaty smart living, smart environment, smart nance, smart mobility, zatem wszystkie aspekty systematy R.Gifingera, które w tym artykule zostały uznane za ist w kontekście badań nad formą urbanistyczną w odniesieniu o Smart City. Przykład ten dowodzi, ze wartosci bliskie ide Smart City moźliwe sa do osiagnięcia takze bez stosowania ozbudowanej ifrastukn jednoznacznie wskazuje na innowacyjność inicjatywy.

\section{Podsumowanie - walidacja kryterium założeń}

Celem artykułu było wykazanie relacji pomiędzy forma urbanistyczna a idea Smart City. Na przykładzie Wiednia i Oslo dowiedziano, że aby uzyskać wartość typu smart konieczne jest uwzglednienie kontekstu miasta, jego tożkoniećne jest uwzględnienie kontéstu miasta, jego toż Wykazano także elementy formy urbanistycznej, które korelują z ideą Smart City.

PRZYPISY 1. Wedtug badań przeprowadzonych przez organizacie RAND: $51 \%$ miast Unii Europe-
jskiej Olicznie mieszkańców wiekszzej niz 1000000 prowadzi prynnaimniej dwa pro-

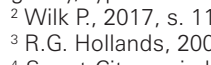

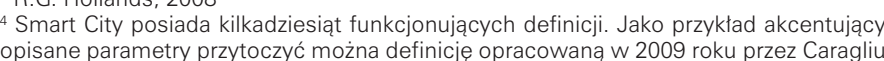

ENDNOTES:

According to RAND analysts $51 \%$ UE cities bigger than 100000
inhabitants is being applying at least two smart city programmes (Manville et al., 2014, p.10
2Wikt P. 2017 p 119

${ }^{2}$ Wilk P. 2017, p. 111
${ }^{2}$ R.G. Hollands, 2008

"There are dozens of functioning definitions of Smart City'. It is Worth to mention the definition by Caragliu A., Del Bo C.. Nijikam A.Wallis, 1977 Pir P. Powell M. at al., 2013
Pires de Miranda 6 Pires de Miranda P. Powell M. at al. 2013
The Crystal in London, a building by Siemens, is both a smart
building and an exhibition presesting the idea of Smart City. For
further details go to the author's article titled The Crystal in London-a new dete
8 Lynch K., 1982
g G 2 .ll S. 2016

10 L.G. Anthopoulos, A.Vakali, 2012
11 The cit's stranstormation into a Smart City may be based on
two models: greenfield (cities created from scratch) and browntwo models: greenfield (cities created from scratch) and brown.
field (existing cities implementing smart values). -Amitrano C.C. Alfano A., Bfulco F., 2014
12 Shelton T. Zook M., Wiig A. 2015
13 lididem, also Nam T., Pardo T.A., 2011

13
14 bidem, also Nam
${ }^{14}$ Vattano $\mathrm{S}, 2013$
Hajer $\mathrm{M}, 2013$

16
116
17

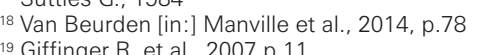
19 Giffinger R. et al., $2007 \mathrm{p} .11$
${ }^{20}$ Proved by the second position in Global Liveability Ranking
2015 [in:! Economist Intelligence Unit lavailable: 10.01.2016] and
the same place according to the CNN station in 2017. 
A.Wallis, 1977

Pires de Miranda P. Powell M. at al., 2013

Budynek firmy Siemens, The Crystal w Londynie, jest jednocześnie obiektem typu smart building, jak i przestrzenią wystawienniczą prezentującą ideę Smart City. Budynek został opisany szerzej przez autorkę w artykule: The Crystal w Londynie - nowy wyznacznik w kreowaniu miast typu smart city?

8 Lynch K. 1982

9 Gzell S., 2016

${ }^{10}$ L.G. Anthopoulos, A.Vakali, 2012

11 Proces podróży miasta w kierunku Smart City może odbywać się na podstawie dwóch modeli nazywanych: greenfield (miasta tworzone od nowa) i brownfield (istniejące miasta implementujace wartości typu smart). -Amitrano C.C. Alfano A., Bifulco F. , 2014

12 Shelton T., Zook M., Wiig A., 2015

13 Ibidem oraz Nam T., Pardo T.A., 2011

14 Vattano S., 2013

${ }^{15}$ Hajer M. 2014

${ }^{16}$ Gzell S., 2016

17 Suttles G. 1984

18 Van Beurden [w:] Manville et al., 2014, s.78

${ }^{19}$ Giffinger R. et al., 2007 s. 11

20 Dane potwierdzone drugą pozycją w Global Liveability Ranking 2015 [w:] Economist Intelligence Unit [dostep: 10.01.2016] oraz tym samym miejscem w badaniach przeprowadzonych

przez stacje CNN w 2017

${ }^{21}$ Rahmenstrategie

22 lbidem

${ }^{23}$ Powierzchnia dzielnicy zajmowac będzie ok. 240 hektarów.

${ }^{24}$ Aspern Seestadt

${ }^{25}$ Aspern Seestadt jest także formą projektu badawczego dotyczącego optymalnych osiedli przyszłości.

${ }^{26}$ Aspern Seestadt

${ }^{27}$ w przypadku Oslo jest to projekt Hovinbyen, obejmujący przebudowę poprzemysłowych dzielnic na atrakcyjne przestrzenie mieszkalno-usługowe.

${ }^{28}$ Smart Retro - novel way to develop cities Baseline Report

29 Jacobs J. [w:] Wilk P. 2017 s. 258

${ }^{30} \mathrm{~Np}$. Projekt Tjuvholmen powstał dzięki finansowaniu inwestorów prywatywnych: Selvaag and Aspelin Ramm. [w:] Oslohavn

\section{LITERATURA/ REFERENCES}

[1] Amitrano C.C, , Alfano A., Bifulco F., New Smart Cities: a focus on some ongoing projects, Conference of Informatics and Management Sciences, 24. - 28.03.2014, s.383-388 [2] Anthopoulos L.G. , Vakali A., Urban Planning and Smart Cities Interrelations and Reciprocities [w:] F. Álvarez et al. (Eds.): FIA 2012, LNCS 7281, s. 178-189, 2012

[3] Caragliu A. Del Bo C. Nijkamp P. Smart cities in Europe, 3rd Central European Conference in Regional Science - CERS, 2009

[4] Hajer M., Europe needs , smart urbanism' not ,smart cities', < https://www. theparliamentmagazine.eu/articles/feature/europe-needs-smart-urbanism-not-smart-cities > - dostep 20.03.2018 [5] Hollands R.G., Will the rea/ smart city please stand up?, City:analysis of urban trends, culture, theory, policy, action, 12:3, 303-320, 2008

[6] Giffinger R. et al., 2007 Smart cities - Ranking of European medium-sized cities, Wiedeń: Centre of Regional Science, $2007<$ http://wWw.smart-cities.eu/ download/ smart cities final report.pdf > - dostęp 15.02.2018

[7] Gzell S., Urban design and the sense of the city, Technical Transactions, 2-A/2016, DOI: $10.4467 / 2353737$ XCT.16.173.5784

[8] Jacobs J. The death and life of great American cities, New York, 1992 [w:] Wilk P. Pojutrze. O miastach przyszłości, Wydawnictwo Literackie, 2017

[9] Lynch K., Obraz Miasta, Wyd. Archivolta, 2014

10] Manville C. et al., 2014, Mapping Smart Cities in the EU, Brussels: European Parliament, Directorate-General for Internal Policies, Policy Department A: Economic and Scientific Policy, Jan. 2014 -dostep 21.02.2016 <http://www.europarl.europa.eu/RegData/etudes/etudes/ join/2014/507480/IPOL-ITRE ET\%282014\%29507480 EN.pdf>

[11] Nam T., Pardo T.A., Smart City as Urban Innovation: Focusing on Management, Policy, and Context, ICEGOV ,11 Proceedings of the 5th International Conference on Theory and Practice of Electronic Governance, Pages 185-194, Tallinn, Estonia - September 26 - 29, 2011

[12] Neuvonen A. et al., Nordic cities beyond digital disruption- novel way to develop cities, Demos Helsinki

[13] Neuvonen A. et al. Smart Retro - novel way to develop cities Baseline Report, Demos Helsinki

[14] Pires de Miranda P., Powell M. at al., Our urban future The Crystal a Suistaunable Cities Initiative by Siemens, Booklink, 2013

[15] Shelton T., Zook M., Wiig A., The 'actually existing smart city', Cambridge Journal of Regions, Economy and Society 2015, 8, 13-25, doi:10.1093/cjres/rsu026

[16] Suttles G., The Cumulative Texture of Local Culture, The American Journal of Sociology, $1984 \mathrm{mb} h$

17] Wallis A., Miasto i przestrzeń. PWN, Warszawa 1977

18] Wilk P. Pojutrze O miastach przyszłości, Wydawnictwo Literackie, 2017

[19] Vattano S., European and Italian experience of Smar t Cities: a model for the smart planning of city built, Techne 05/2013, Firenze University Press

20] $h$ ttps://www.thecrystal.org - dostęp 20.04.2017

21] http://Www.ascr.at/en/smart-building/- dostęp 30.04.2017

[22] https://www.focus.pl/artykul/10-najlepszych-miast-do-zycia-ranking-przygotowany-przez-cnn?page =2 - dostep 20.04.2018

[23] http://smartretro.demoshelsinki.fi/ [dostęp: 5.03.2018]

24] Rahmenstrategie [w:] Smart city Wien, [dostęp:1.03.2018], <https://smartcity.wien.gv.at/ site/en/initiative/rahmenstrategie/>

25] Aspernseestadt https://www.aspern-seestadt.at/wirtschaftsstandort/architektur staedtebau [dostep:1.03.2018]

[26] Oslohavn <https://www.oslohavn.no/en/fjord_city/tjuvholmen/> [dostęp: 15.03.2018],
${ }^{21}$ Rahmenstrategie

22 bidem

${ }^{23}$ The area of the district will be about 240 hectares.

${ }^{24}$ Aspern Seestadt

${ }^{25}$ Aspern Seestadt is also a form of a research project on optimal settlements of the future.

${ }^{26}$ Aspern Seestadt

27 In the case of Oslo: Hovinbyen project- the revitalisation of postindustrial districts into an attractive residential and service area.

${ }^{28}$ Smart Retro - novel way to develop cities Baseline Report 29 Jacobs J. [in:] Wilk P. 2017, P. 258

${ }^{30}$ For example, the Tjuvholmen project was founded by private investors: Selvaag and Aspelin

\section{LITERATURA/ REFERENCES}

[1] Amitrano C.C, , Alfano A., Bifulco F., New Smart Cities: a focus on some ongoing projects, Conference of Informatics and Management Sciences, 24. - 28.03.2014, s.383-388

[2] Anthopoulos L.G. , Vakali A., Urban Planning and Smart Cities Interrelations and Reciprocities [w:] F. Alvarez et al. (Eds.): FIA 2012, LNCS 7281, s. 178-189, 2012

[3] Caragliu A., Del Bo C., Nijkamp P. Smart cities in Europe, 3rd Central European Conference in Regional Science - CERS, 2009

[4] Hajer M., Europe needs ,smart urbanism' not smart cities' <https://www theparliamentmagazine eu/articles/ feature/europe-needs-smart-urbanism-not-smart-cities > dostep 20.03.2018

[5] Hollands R.G., Will the real smart city please stand up? City:analysis of urban trends, culture, theory, policy, action, $12: 3,303-320,2008$

[6] Giffinger R. et al., 2007 Smart cities - Ranking of European medium-sized cities, Wiedeń: Centre of Regional Science, 2007 <http://Www.smart-cities.eul download/ smart_cities final report.pdf > - dostęp 15.02.2018

[7] Gzell S., Urban design and the sense of the city, Technical Transactions, 2-A/2016, DOl: 10.4467/2353737XCT 16.173.5784

[8] Jacobs J. The death and life of great American cities, New York, 1992 [w:] Wilk P. Pojutrze. O miastach przyszłości, Wydawnictwo Literackie, 2017

[9] Lynch K., Obraz Miasta, Wyd. Archivolta, 2014

[10] Manville C. et al., 2014, Mapping Smart Cities in the EU Brussels: European Parliament, Directorate-General for Internal Policies, Policy Department A: Economic and Scientific Policy, Jan. 2014 -dostęp 21.02.2016 < http://www.europarl.europa.eu/RegData/etudes/etudes/join/2014/507480/ IPOL-ITRE ET\%282014\%29507480 EN.pdf

[11] Nam T., Pardo T.A., Smart City as Urban Innovation: Focusing on Management, Policy, and Context, ICEGOV , 11 Proceedings of the 5th International Conference on Theory and Practice of Electronic Governance, Pages 185194. Tallinn, Estonia - September 26 - 29, 2011

[12] Neuvonen A. et al., Nordic cities beyond digital disruption- novel way to develop cities, Demos Helsinki

[13] Neuvonen A. et al. Smart Retro - novel way to develop cities Baseline Report, Demos Helsink

[14] Pires de Miranda P., Powell M. at al., Our urban future The Crystal a Suistaunable Cities Initiative by Siemens, Booklink, 2013

[15] Shelton T., Zook M., Wiig A., The 'actually existing smart city', Cambridge Journal of Regions, Economy and Society 2015, 8, 13-25, doi:10.1093/cjres/rsu026

[16] Suttles G., The Cumulative Texture of Local Culture, The American Journal of Sociology, 1984mb h

[17] Wallis A., Miasto i przestrzeń. PWN, Warszawa 1977

[18] Wilk P. Pojutrze. O miastach przyszłości, Wydawnictwo Literackie, 2017

[19] Vattano S. European and Italian experience of Smar Cities: a model for the smart planning of city built, Techne 05/2013, Firenze University Press

[20] https://www.thecrystal.org - dostęp 20.04.2017

[21] http://Www.ascr.at/en/smart-building/- dostęp 30.04.2017

[22] https://www.focus.pl/artykul/10-najlepszych-miast-do-zycia-ranking-przygotowany-przez-cnn?page=2 - dostęp 20.04.2018

[23] http://smartretro.demoshe/sinki.fil [dostęp: 5.03.2018] [24] Rahmenstrategie [W:] Smart city Wien, [dostęp:1.03.2018], <https://smartcity.wien.gv.at/site/en/initiative/rahmenstrategie/>

[25] Aspernseestadt https://www.aspern-seestadt. at/wirtschaftsstandort/architektur staedtebau dostẹp:1.03.2018]

[26] Oslohavn <https://www.oslohavn.no/en/fjord city/ tjuvholmen/> [dostęp: 15.03.2018] 